\title{
The Regional Tax Security Mechanism Based on Reduction of Tax Risks and Use of Information Technologies
}

\author{
L.V. Popova ${ }^{1}, M . V$. Selyukov $^{2}$, N.G. Varaksa ${ }^{1}$ and M.A. Nazarov ${ }^{3, *}$ \\ "Corresponding author: good_mn@mail.ru \\ ${ }^{1}$ Orel State University, Orel, Russia \\ ${ }^{2}$ Surgut State University, Surgut, Russia \\ ${ }^{3}$ Samara State University of Economics, Samara, Russia
}

\begin{abstract}
In today's world taxes tend to be not only a tool for ensuring and maintaining economic and financial security, but also a source of possible threats and risks which may result in reduction of tax potential and budgetary imbalances between the central office and the provinces. In the conditions of economy digitalization, tax security as a prospective way of optimal modern tax management in the state and its regions includes elements of tax mechanism, information technology and technology of tax information protection. This article advocates the need for legislative recognition of the term "tax security", structures the components of tax security threats identification, which include elements of risk management and directions of tax administration improvement. Within the framework of the study of the tax security system, the functional relationship between tax risks and the structural elements of the tax mechanism, including its planning, regulatory, controlling and analytical components, was determined.
\end{abstract}

Keywords: information technology, tax security, tax mechanism, tax risks, region.

\section{Introduction}

In current conditions of social and economic development of the state and digitalization of the economy, the failures of ineffective tax policy, which may be caused by management mistakes and the influence of various negative external and internal factors, enhances the tax security threats. In the perspective it may negatively affect the development of the budget and financial systems of the state generally.

\section{Problem Statement}

The disproportions in the socio-economic development of regions are determined not only by the natural and climatic features and investment potential, but also by the ways of using the elements of tax mechanism, which is the basic regulator of the regional tax policy. In this regard, the issues of threat identification and ensuring national security through management, control and analytical elements of the tax mechanism, as well as the system of modern information technologies are becoming increasingly relevant and important. The lack of theoretical and practical development of the highlighted problem determines the need to identify threats and uncertainties in the tax environment from the perspective of ensuring the tax security of a region.

\section{Research Questions}

The tax security of state was studied by many scholars (Butylin [1], Tsviliy-Buklanova [2, 3], Lobov \& Gvarliani [4]) in terms of the effectiveness of the tax policy that optimally combines the interests of participants in tax relations. Russian researchers (Vorontsov [5], Mironova [6], Selyukov [7, 8], Efremova \& Efremova [9]) distinguish institutional and functional approaches to ensuring tax security. At the same time, the system of tax security is functionally realized through a set of measures and tools aimed at preventing, identifying and suppressing the main threat - tax risks. Panskov [10, 11], Viktorova [12], Mukhamedzhanova [13], Vlasova [14], Gorokhova [15] and other scholars focus on studies of tax and budget risks as well as the process of risk management. Researchers identify elements of tax administration as basic tools for ensuring tax security in the region [16-22].

The following key research questions can be highlighted: an analysis of existing approaches to ensuring tax security of a region and identification of threat sources; studying the process of tax risk management; determination of the structure of a single center for generating the information database of tax authorities and directions for improving the tax administration system; establishment of functional relationship between tax risks and elements of the tax mechanism in the system of ensuring the tax security of region. 


\section{Purpose of the Study}

The purpose of this study is to review the existing approaches to ensuring tax security and tax risks reduction, as well as author's approach to structuring the elements of identification of treats and uncertainties in the tax sphere for the purposes of achieving tax security in the region. This leads to the revealing of functional connection between tax risks and structural elements of tax mechanism on the basis of planning, regulatory, control and analytical aspects.

\section{Research Methods}

Within the framework of this study, the methods of scientific search, comparison, graphic construction, synthesis, modelling, abstraction and concretization were applied.

The practical application of risk identification elements together with tax mechanism instruments enables the prediction of potential positive or negative outcomes within the implementation of particular measures of regional tax policy and allows taking initial steps to minimize the negative impact of tax security threats on the socio-economic development of the state and its regions.

\section{Findings}

While understanding the full importance of the category "security" and its ensuring mechanisms, we consider it reasonable to give the term a legislative implementation and define it as a tax system condition, which provides a harmonious development of the tax sphere, opportunities of applying tax instruments in order to guarantee the state interests protection, the maintenance of socio-economic stability in society, as well as establishing the system of financial resources, able to counteract both predictable and unpredictable internal and external threats successfully.

The study revealed that the main source of tax security threats of the state are tax risks. Tax risks are associated with a specific event of stochastic nature. They tend to occur in conditions of insufficient tax legislation, the dual interpretation of legal regulation, the use of illegal tax schemes and the implementation of inefficient tax policy. The process of tax risk management is defined as a mechanism of relevant identification of threats and uncertainties, analysis and assessment of tax situation and establishment of measures to prevent or reduce negative impacts on the economic entity or state (Figure 1).

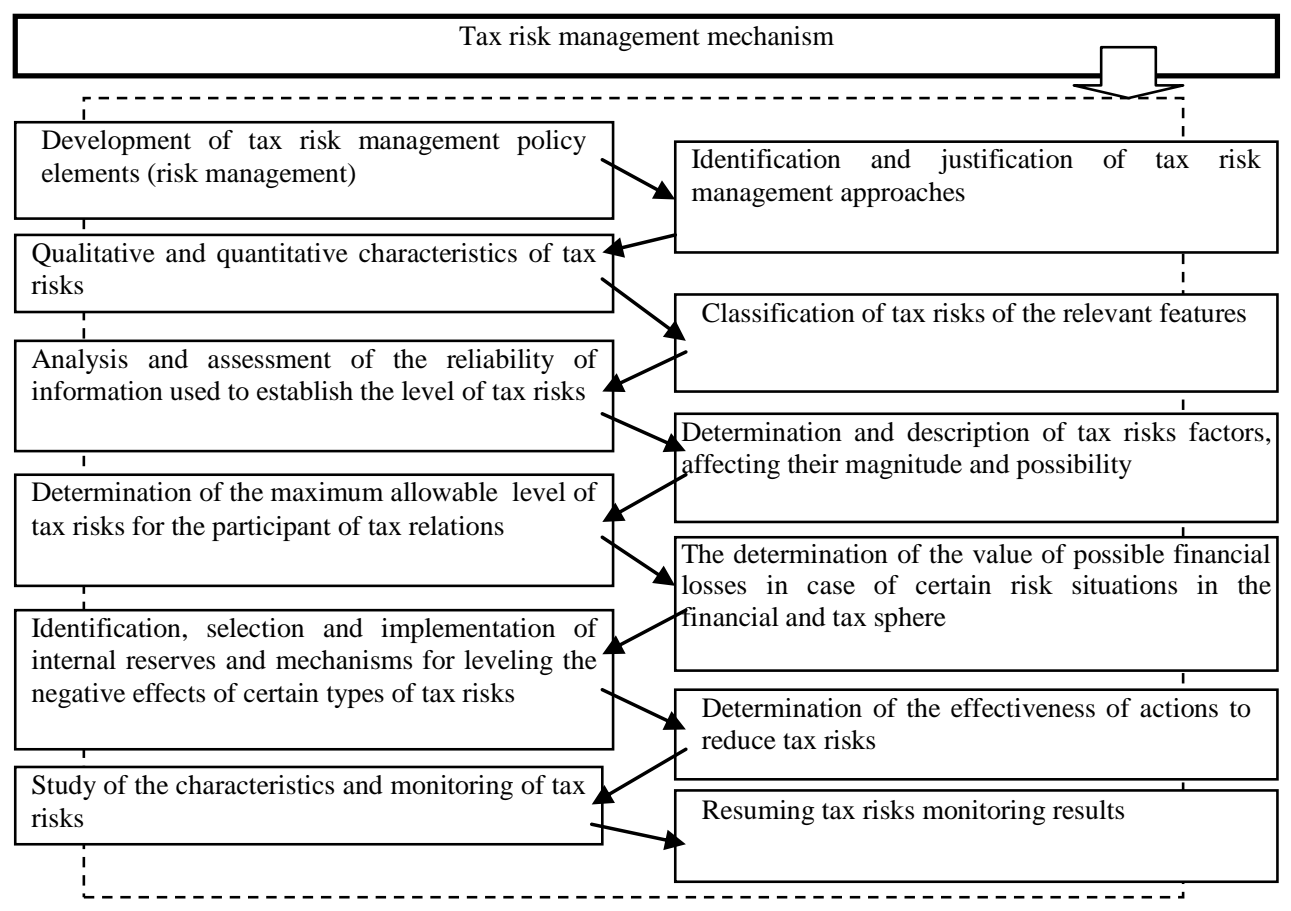

Figure 1. Tax risk management mechanism (Source: compiled by the authors)

The study found that the reasonable maximum permissible (critical) level of tax risk should not exceed $50 \%$ of the total tax debt from actually received taxes (Table 1). The predicted share of total tax debt in the total tax revenues in a region does not exceed the established allowable level of 50\%. However, the growth of tax debt in the mid-term perspective should be under strict control and get subjected to detailed analysis by regulatory authorities in order to ensure an adequate level of tax security in the region. 
Such arrangements as effective operation of a unified data processing center and development of tax authorities' database providing information about taxpayers, financial and economic activities and socio-economic situation in Russian regions may be suggested as preventive measures to increase the efficiency of regional tax authorities.

Table 1. Assessment of the level of tax risk in the regions of the Russian Federation

\begin{tabular}{|l|c|c|c|c|}
\hline \multirow{2}{*}{ Criteria } & \multicolumn{2}{|c|}{ Orel region } & \multicolumn{2}{c|}{ Tyumen region } \\
\cline { 2 - 5 } & 2016 г. & 2017 г. & 2016 г. & 2017 . \\
\hline Total taxes received, mln. rub. & 22764 & 28418 & 155848 & 96142 \\
\hline $\begin{array}{l}\text { Total tax indebtedness, mln. } \\
\text { rub. }\end{array}$ & 3828 & 3451 & 7189 & 9457 \\
\hline Tax risk level, \% & 16,8 & 12,15 & 4,61 & 9,84 \\
\hline $\begin{array}{l}\text { The maximum permissible } \\
\text { level of tax risk }\end{array}$ & $\leq 50 \%$ & $\leq 50 \%$ & $\leq 50 \%$ & $\leq 50 \%$ \\
\hline
\end{tabular}

Source: compiled by the authors.

In the process of ensuring regional tax security, it is necessary to take into account interrelation of tax risks not only with managerial factor, but also with other structural elements of tax mechanism (Fig. 2).

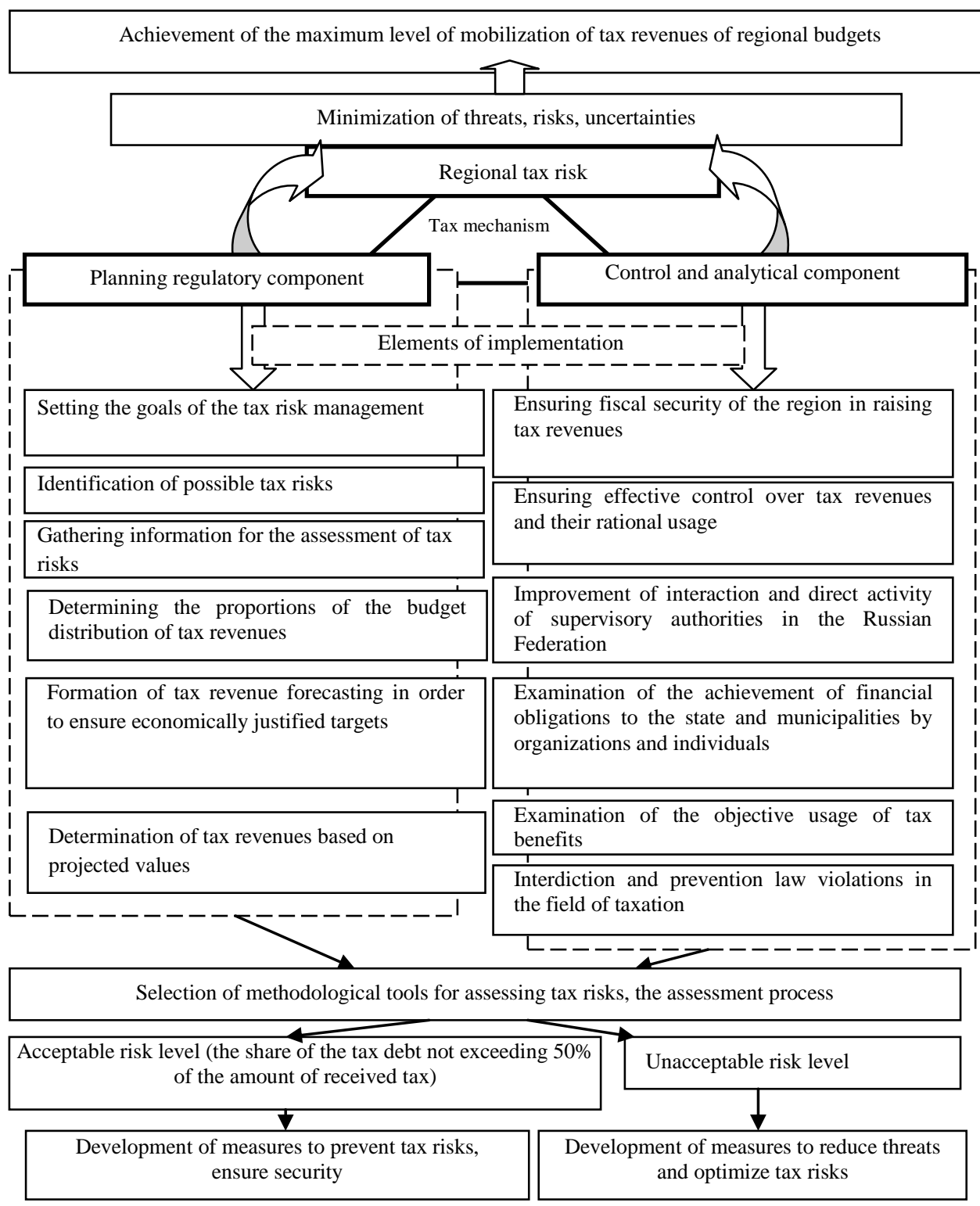

Figure 2. Functional interrelation of tax risks and elements of the tax mechanism in providing of the regional tax security system (Source: compiled by the authors)

In order to ensure tax security, the following areas were defined for improving tax administration system:

1) introduction into the scientific practice such category as "tax amnesty". This meets the demands of modern society, particularly it stimulates the growth of social welfare and reduces social tension; 
2) introduction of the term "tax disqualification" into legislation and professional practice and establishing criteria for the application of tax disqualification, the mechanism for its implementation, the possible periods and reasons for the tax disqualification of individuals and legal entities.

\section{Conclusion}

Tax system and tax policy play significant role in ensuring the tax security of the state and depend on specific situation and features of the country's development. It is proved that the implementation of a unified tax policy that provides the balance of interests of all tax parties, tax administration system development will facilitate eliminating threats and ensuring tax security.

In regional tax security system the effective usage of tax mechanism instruments should be focused on a steady development of the real sector of the economy and guaranteeing region's financial self-sufficiency via state support, by stimulating economic activity of the territories and improving the efficiency of using the resource potential.

\section{Acknowledgments}

The paper was prepared under the state project No. 26.2758.2017/4.6 for 2017-2019 years "System of analysis of the formation and distribution of the cost of innovative products based on the infrastructure concept."

\section{References}

1. D.V. Butylin, Problems of ensuring of tax security. Vestnik of South Ural State University, 13, 224-227. URL: http://cyberleninka.ru/article/n/problemy-obespecheniya-nalogovoy-bezopasnosti (2006). [in Rus.].

2. A.A. Tsviliy-Buklanova, Tax security of the state - an essential object of legal regulation. Actual Issues of Economic Sciences, 44, 76-85 (2015). [in Rus.].

3. A.A. Tsviliy-Buklanova, Threats to Russia's tax security in the context of modern state development. Vestnik of Omsk University, 1, 41-48. URL: https://cyberleninka.ru/article/n/ugrozy-nalogovoy-bezopasnosti-rossii-vkontekste-sovremennogo-razvitiya-gosudarstva (2010). [in Rus.].

4. S.R. Lobov, I.E. Gvarliani, Formation of an economic mechanism to ensure tax security. Vestnik of the Sochi State University of Tourism and Resort Business, 3(17), 77-80. URL: http://vestnik.sutr.ru/journals n/1317916915.pdf (2011). [in Rus.].

5. B.V. Vorontsov, Tax security of the state and economic systems. Problems of the Modern Economy, 3(27), 586-588. Retrieved from: http://www.m-economy.ru/art.php?nArtId=2199 (2008). [in Rus.].

6. O.A. Mironova, Tax security: the development of the theory, methodology and practice. Innovative Development of the Economy, 3-1(33), 90-97 (2016). [in Rus.].

7. M.V. Selyukov, The concept of the influence of elements of the tax mechanism on the state tax security. Economic and Human Sciences, 9(272), 65-71 (2014). [in Rus.].

8. M.V. Selyukov, Providing regional tax security by reducing tax risks. Management Accounting, 7, 72-79 (2016). [in Rus.].

9. T.A. Efremova, L.I. Efremova, Information and technological bases of tax administration modernization. Finance and Control, 1, 212-236 (2012). [in Rus.].

10. V.G. Panskov, Tax risks: taxpayers and the state. Tax Vestnik, 1, 3-7. URL: https://www.lawmix.ru/bux/36627 (2009). [in Rus.].

11., V.G. Panskov The interrelation of tax risks of taxpayers and the state. Taxes and Taxation, 12, 18-22. URL: https://www.lawmix.ru/bux/35519 (2008). [in Rus.].

12. N.G. Viktorova, Classification basis for tax risks. Problems of Risk Analysis, 2, 26-29 (2013). [in Rus.].

13. S. Mukhamedzhanova, The impact of state tax policy on reducing tax risks. In B. Abdraim (Ed.) Collection of articles of the $2^{\text {nd }}$ republic scientific student conference "20 years of independence of Kazakhstan and the formation of civil society», (pp. 200-203). Astana, Kazakhstan: Eurasian National University named after L.N. Gumilyov. URL: https://refdb.ru/look/1089342-pall.html (2011). [in Rus.].

14. Y.A. Vlasova, Risks of regional budgets of the Russian Federation. Espacios, 38(52), 10. URL: http://www.revistaespacios.com/a17v38n52/17385210.html (2017).

15. D.V. Gorokhova, Budgetary risk management of the Russian Federation: Modern look and prospects. Financial Journal, 3, 55-62. URL: http://www.nifi.ru/images/FILES/Journal/Archive/2013/3/statii/2013_03_06.pdf. (2013). [in Rus.].

16. V.A. Hochuev, Optimization of tax administration as a factor in increasing tax security. Tax Policy and Practice, 81, 12-14 (2009). [in Rus.].

17. V.S. Bochko, The accelerating and constraining factors of the coordinated and balanced development of regions. Economy of Region, 1(1), 39-52. DOI: 10.17059/2015-1-4 (2015). [in Rus.]. 
18. E.V. Nikulina, I.V. Chistnikova, A.V. Orlova, Modeling and forecasting the fiscal security of the regions of Russia: monograph. Belgorod: LLC

"Epicenter".

URL: http://dspace.bsu.edu.ru/bitstream/123456789/13443/1/Nikulina_modelirovanie2015.pdf (2015). [in Rus.].

19. E.V. Porollo, V.V. Kazakov, Tax control and tax administration in the system of principles for the effective and responsible management of public finances. Vestnik of Tomsk State University, 320, 172-175. URL: http://sun.tsu.ru/mminfo/000063105/320/image/320-172.pdf (2009). [in Rus.].

20. J. Nussim, A.D. Tabbach, Deterrence and tax treatment of monetary sanctions and litigation costs. International Review of Law and Economics, 29(1), 1-7. DOI: 10.1016/j.irle.2008.01.001 (2009).

21. K.M. Musaeva, The increase of tax administration effectiveness, as a factor of shadow sector validation and growth of economic security. Life Science Journal, 11(7s), 229-233. URL: http://www.lifesciencesite.com/lsj/life1107s/046_24554life1107s14_229_233.pdf (2014).

22. V. Nasyrova, Estimation of the quality of tax administration in the Russian Federation. Mediterranean Journal of Social Sciences, 6(1S3), 16-19. DOI: 10.5901/mjss.2015.v6n1s3p16 (2015). 